\title{
Concentrations of heavy metals and pesticide residues in leafy vegetables and implications for peri-urban farming in Nairobi, Kenya
}

\author{
Nancy N. Karanja ${ }^{a}$, Mary Njenga* ${ }^{a *}$ G. K Mutua ${ }^{a}$, C. J. Lagerkvist ${ }^{b}$, E. Kutto ${ }^{a}$, and J. J. Okelloa
}

Submitted 8 April 2011 / Revised 18 November 2011, 16 April 2012, and 1 May 2012 / Accepted 2 May 2012 /

Published online 22 October 2012

Citation: Karanja, N. K., Njenga, M., Mutua, G. K., Lagerkvist, C. J., Kutto, E., \& Okello, J. J. (2012). Concentrations of heavy metals and pesticide residues in leafy vegetables and implications for peri-urban farming in Nairobi, Kenya. Journal of Agriculture, Food Systems, and Community Development, 3(1), 255-267. http://dx.doi.org/10.5304/jafscd.2012.031.003

Copyright (C) 2012 by New Leaf Associates, Inc.

\begin{abstract}
The primary objective of this study was to assess the levels of heavy metals, nitrate, and pesticide residues in kale (Brassicaolaracea var. olecephala), a leafy vegetable. The study was conducted in three peri-urban sites in Nairobi, Kenya, where the use of wastewater irrigation is pervasive. The results indicated elevated levels of boron (B), cobalt (Co), chromium $(\mathrm{Cr})$, copper $(\mathrm{Cu})$, lead $(\mathrm{Pb})$, zinc $(\mathrm{Zn})$ and nickel $(\mathrm{Ni})$ in vegetables irrigated with wastewater in two sites. High loadings of the heavy metals $\mathrm{Ni}$, arsenic (As), $\mathrm{Pb}, \mathrm{Cr}, \mathrm{Cu}$, and $\mathrm{Zn}$ into agricultural soils were demonstrated to be from chicken manure. Nitrate levels were within
\end{abstract}

a University of Nairobi; P.O. Box, 30197-00100; Nairobi, Kenya; nancy.karanja@cgiar.org; kyalloh@yahoo.com; yonkutt@yahoo.com; jijokello@gmail.com

b Swedish University of Agricultural Sciences; P.O. Box 7013; Johan Brauners vag 3, SE-750 07; Uppsala, Sweden; carljohan.lagerkvist@ekon.slu.se

* Corresponding author: Mary Njenga, m.njenga@,cgiar.org acceptable daily intakes. Residues of diazinon, cypermethrin, biternol, and profenofos pesticides exceeded permissible maximum residue limits in kale at one site. Study findings suggest that consumers of vegetables grown in wastewaterirrigated soils may ingest significant amounts of heavy metals and pesticides. Considering these findings, reducing heavy metal deposits into soils should be a strategic aim of soil protection policies in Kenya.

\section{Keywords}

food safety, heavy metal concentrations, leafy vegetables, peri-urban, pesticide residue

\section{Introduction}

Change in dietary preferences, incomes, and urbanization have increased the demand for leafy vegetables, which has led to increased production of these vegetables in Kenya in the past decade (Onyango, Shibairo, Imungi, \& Harbinson, 2008). Vegetable production systems are often characterized by intensive use of fertilizers and pesticides 
(Nugent, 2000). This is in response to consumers' demand for vegetables with characteristics such as spotlessness, freshness, and that are pest and disease-free.

The quality of water used to irrigate vegetable crops in the vicinity of cities in low- and middleincome countries has been compromised by rapid urbanization that has not been matched by improvements in water and sanitation infrastructure (Nabulo, Oryem-Origa, Nasinyama, Cole, \& Diamond, 2008). Surface and well waters have consequently been exposed to contamination by industrial effluents and uncontrolled sewage, leading to the accumulation of heavy metals and other toxic materials in soil and crops, particularly leafy vegetables (Abdel-Ghani, Hefny, \& ElChaghaby, 2007). Similarly, anthropogenic inputs associated with industrialization and agricultural deposition, such as atmospheric deposition, waste disposal, waste incineration, urban effluent, traffic emissions, fertilizer application, and long-term application of wastewater in agricultural land, contribute to heavy metal accumulation (Ensink \& Simmons, 2004; Emongor, 2007). Previous studies in Kenya, Uganda, Senegal, Ghana, and Pakistan have shown that use of irrigation water mixed with industrial effluent led to accumulation of toxic metals and excessive nitrates in plants (Keraita et al., 2002; Kar et al., 2007; Karanja et al., 2010).

Build-up of heavy metals contaminants in agricultural soils is of increasing concern due to potential health risks as well as detrimental effects on soil ecosystems (Qishlaqi, Moore, \& Forghani, 2008). Health risks associated with wastewater include exposure to heavy metals from industrial effluent and microbiological contaminants WHO, 2006). Heavy metals are particularly hazardous because elements such as nickel $(\mathrm{Ni})$, cadmium $(\mathrm{Cd})$, chromium $(\mathrm{Cr})$, and lead $(\mathrm{Pb})$ can lead to hepatomegaly (enlarged liver) and increase the likelihood of cancer, congenital malformation, and bone and kidney disorders (Kakar, Yasinzai, Salarzai, Oad, \& Siddqui, 2006).

Poor pollution-control policy and weak enforcement of industry zoning regulations have led to widespread vegetable production on parcels of land that are close to industrial and manufacturing plants and therefore prone to water and air pollution. Other pollutants from nonpoint pollution sources such as construction sites, auto garages, and oil residue and exhaust gas emissions at highways exacerbate the problem of heavy metal accumulation in peri-urban and urban farming areas. In addition, the accumulation of heavy metals in ecosystems has been attributed to excessive fertilizer and pesticide use, especially phosphates (Aydinalp \& Marinova, 2003).

Some studies on public health risks associated with heavy metals have shown the necessity of measuring the accumulation of heavy metals since they pose serious health hazards to human health (Keraita et al., 2002; Nabulo, 2008; Kar et al., 2007; Karanja et al., 2010). In this study, we assess the contamination of irrigation water by more abundant metals such as boron, copper, zinc, and manganese, as well as pesticide residues, which may sometimes pose greater hazard than lead, mercury, and cadmium (Cornish \& Kielen, 2004).

Pesticide bioaccumulation and biomagnification have become the weak links in the food chain. Some studies show an association between exposure to pesticides and health problems such as cancer, attention deficit (hyperactivity) disorder, and nervous system disorders, and suggest that exposure to pesticides could weaken the immune system (Faruqui, Niang, \& Redwood, 2004; Kakar et al., 2006; Karanja et al., 2010). In this study, we explore pesticide bioaccumulation in the leafy vegetable kale that is grown in peri-urban areas of Nairobi. Kale is the most commonly grown and consumed fresh vegetable by both rural and urban households in Kenya and plays an important role in nutritional balance in developing countries (Okello, Lagerkvist, Hess, Ngigi, \& Karanja, 2012).

\section{Methodology and Approaches}

\section{Sampling Sites}

Nairobi is at an elevation of 5,480 feet $(1,670$ meters) above sea level and covers an area of 270 square miles (700 square kilometers). The city and its environs receive 41 inches (1,050 millimeters) of rainfall, which is bimodal, with the long rains falling between March and May and the short rains between October and December. The mean annual temperature is $62.6^{0} \mathrm{~F}\left(17^{\circ} \mathrm{C}\right)$, while the 
mean daily maximum and minimum temperatures are $73.4^{\circ} \mathrm{F}\left(23^{\circ} \mathrm{C}\right)$ and $53.6^{\circ} \mathrm{F}\left(12^{\circ} \mathrm{C}\right)$, respectively (Foeken \& Mwangi, 2001). While irrigation activity is expected to occur during the driest months (June and September), for more than 90 percent of farmers, irrigation is a year-round activity.

\section{Study Area}

Three peri-urban farming areas were selected based on production practices, proximity to industries, and major roads and age of settlement (figure 1). Athi River is an industrial area, while Ngong and Wangige comprise farms of recent settlement and those occupied for over 50 years, respectively. The Athi River site has several manufacturing industries, meat processing plants, wine distillers, and hide and skin processing industries. Most of the farmers in this area utilize water from the Athi River to grow vegetables using furrow irrigation. A small number of farmers exploit untreated effluent water from the meat processing plant. In the Ngong site, farmers use water from streams that flow from the Ngong Hills for the production of kale and spinach. A few farmers use highly con- taminated stream water at the Kiserian town, in Ngong. The farmers in Wangige utilize water from streams or boreholes.

\section{Kale, Soil, and Water Sampling}

We collected samples of kale, soil, and water from 60 peri-urban farms (Athi River, $\mathrm{n}=16$; Ngong, $\mathrm{n}=22$; and Wangige, $\mathrm{n}=22$ ). From these farms, kale leaves were picked randomly from various locations of the sample plot by moving in a zigzag manner across the plot while picking leaves from lower, middle, and upper part of each selected plant. Samples from each plot were pooled and mixed, and a subsample of 17.6 ounces (500 grams) was put into a sterile paper bag for analysis. We took irrigation water samples at the source aseptically into sterile bottles and transported them to a laboratory, where they were analyzed. Since chicken manure is the main source of vegetable nutrients, chicken manure samples were collected in the same manner in farms from Wangige. Sampling was done for both the wet and dry season in Ngong and Athi River. However, in Wangige, water samples for heavy metal analysis

\section{Figure 1. Map Showing Ngong, Wangige, and Athi River Peri-urban Agricultural Areas}

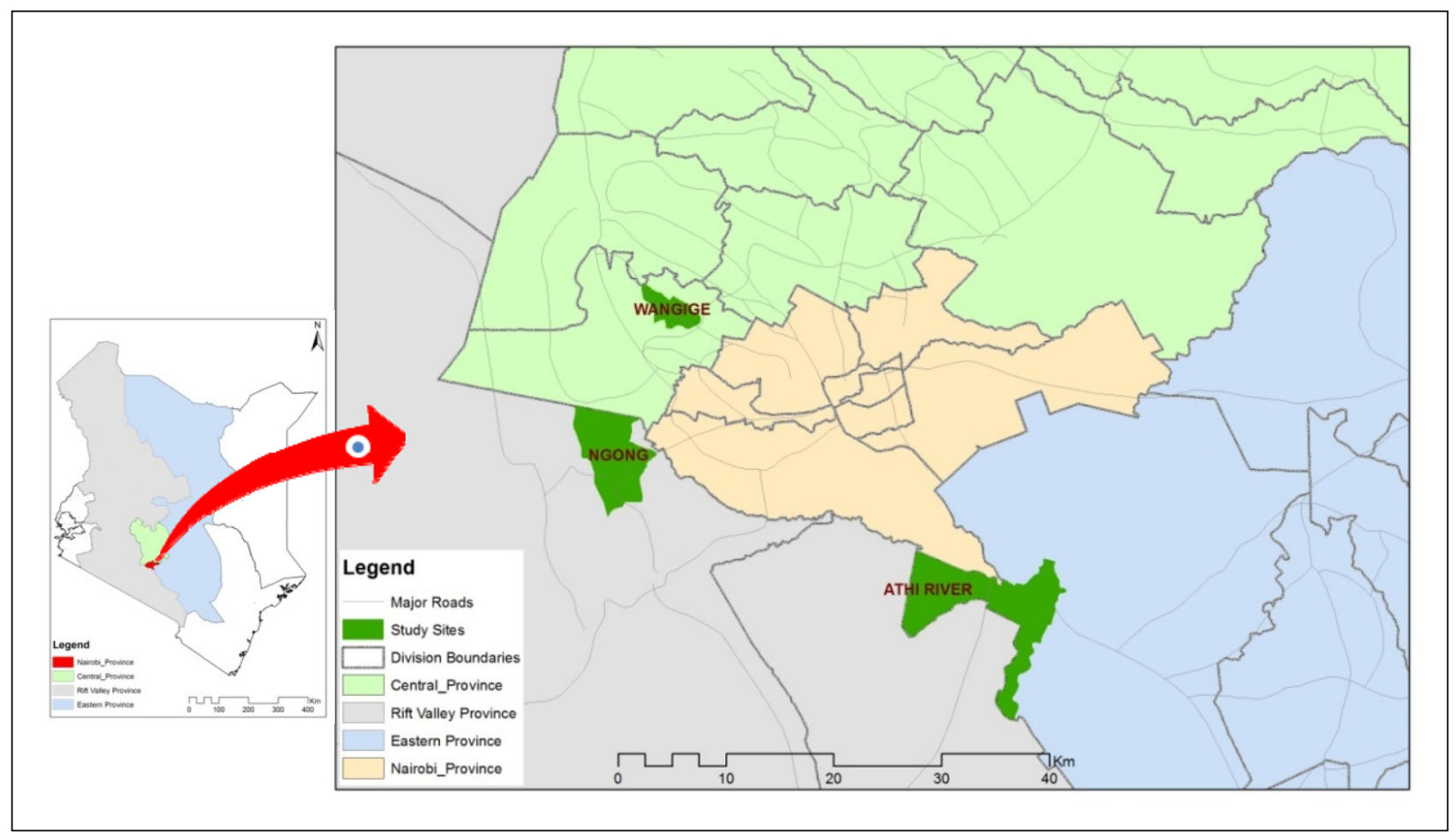


were collected only once since there was no threat of heavy metal contamination as farmers use borehole water for irrigation.

\section{Laboratory Analysis}

Soil and manure samples were air-dried to constant weight and then sieved through a $2 \mathrm{~mm}$ mesh wire. One gram of soil was digested in 9 $\mathrm{ml}$ aqua regia $\left(1: 3 \mathrm{HNO}_{3}: \mathrm{HCl}\right)$ then passed through Whatmann filter No. 1 and directly aspirated into an inductively coupled plasma (ICP) spectrophotometry for determination of heavy metals (MoenkeBlankenburg, 1993). Water samples for heavy metal analysis were directly aspirated into the ICP. The kale tissues were oven dried at $140^{\circ} \mathrm{F}\left(60^{\circ} \mathrm{C}\right)$ for eight hours and $0.5 \mathrm{~g}$ was transferred into a crucible and dry-ashed at $122^{\circ} \mathrm{F}\left(50^{\circ} \mathrm{C}\right)$ for 6 hours and then extracted with mild aqua regia $\left(3 \mathrm{ml} \mathrm{HCl} 5 \mathrm{M}+0.25 \mathrm{ml}\right.$ conc $\mathrm{HNO}_{3}$ ) evaporated on a hot plate (Campbell \& Plank, 1997) to determine the total concentrations of $\mathrm{As}, \mathrm{Co}, \mathrm{Cu}, \mathrm{Fe}, \mathrm{Pb}, \mathrm{Mn}, \mathrm{Ni}$, and $\mathrm{Zn}$ in filtrate using the ICP spectrophotometry. Total heavy metal concentrations in chicken manure samples were determined by digesting $200 \mathrm{~g}$ (fresh weight) samples with aqua regia and analyzing them as above.

\section{Statistical Analysis}

Statistical analyses were performed using XLSTAT. ANOVA and $\mathrm{t}$ test were used for comparison of means between seasons. Principal Component Analysis (PCA) was performed to establish possible factors that contribute to the metal concentrations and source apportionment. All data sets were subjected to Factor Analysis (FA). The number of significant Principal Components $(P C)$ was selected on the basis of Varimax orthogonal rotation with Kaiser Normalization with eigenvalue greater than 1 .

\section{Results and Discussion}

Heavy Metal Concentration in Irrigation Water

Concentrations of As in water were not statistically significant among

Figure 2. Heavy Metal Concentrations in Irrigation Water in Peri-urban Sites During Nairobi (a) Dry and (b) Wet Seasons (Athi River, $n=16$; Ngong, $n=22$; and Wangige, $n=22$

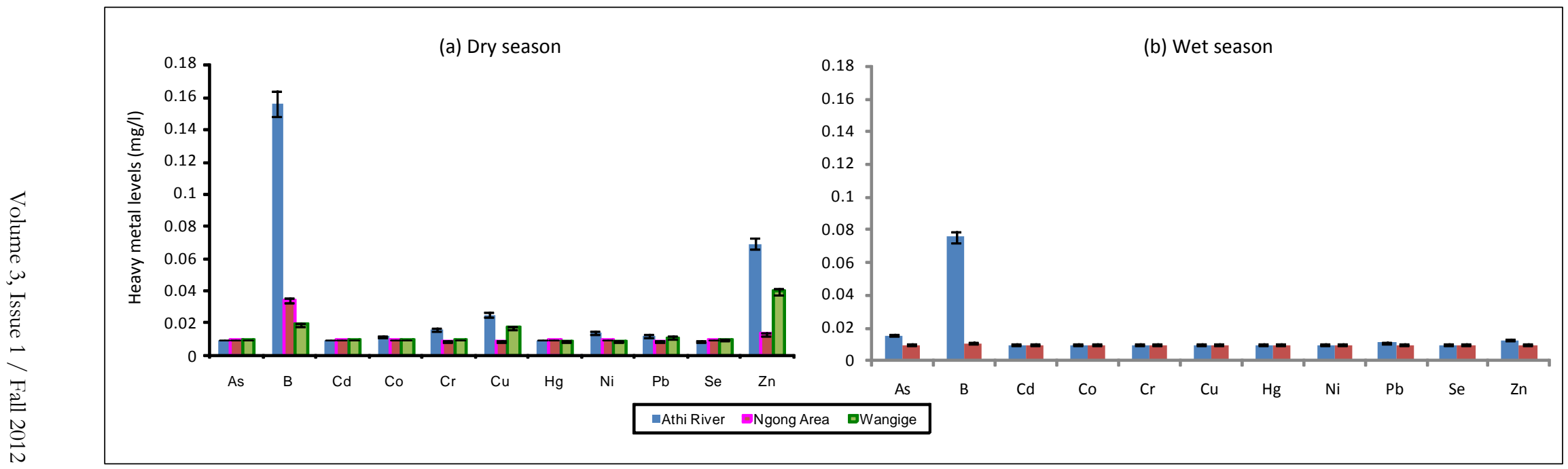


the three sites in the dry season, but were significantly elevated in the wet season, with the highest levels recorded at Athi River (figure 2). William (2001) also observed that As concentrations in mine waters increased in the wet season compared to the dry season. Such seasonal variation in the concentration of As could be attributed to differences in individual As solubility, $\mathrm{pH}$, and leaching by acidic rain during the wet season (Iwegbue, Egobueze, \& Opuene, 2006). Similarly, in the wet season, As concentration in Athi River was significantly higher than in Ngong. Elevated heavy metal concentration in Athi River may be due to effluents from nearby manufacturing industries, meat processing plants, wine distillers, and hide and skin processing industries. Boron levels in irrigation water from Athi River $(0.074$ $\mathrm{mg} / \mathrm{L} \mathrm{B})$ were elevated compared to Ngong (0.034 $\mathrm{mg} / \mathrm{L} \mathrm{B})$ and Wangige $(0.019 \mathrm{mg} / \mathrm{L} \mathrm{B})$. In both seasons, boron concentrations were consistently highest in Athi River. In general, heavy metal concentrations of $\mathrm{Co}, \mathrm{Cr}, \mathrm{Cu}$, and $\mathrm{Ni}$ were significantly higher in the dry season compared to the wet season. Action of water dilution could be the main reason for the reduction in heavy metal concentrations during the wet season (with the exception of As) (Iwegbue et al., 2006).

While boron is essential for plant development

\section{Figure 3. Principal Component Analysis of Metal Concentrations in the Three Peri-urban Sites in Nairobi}

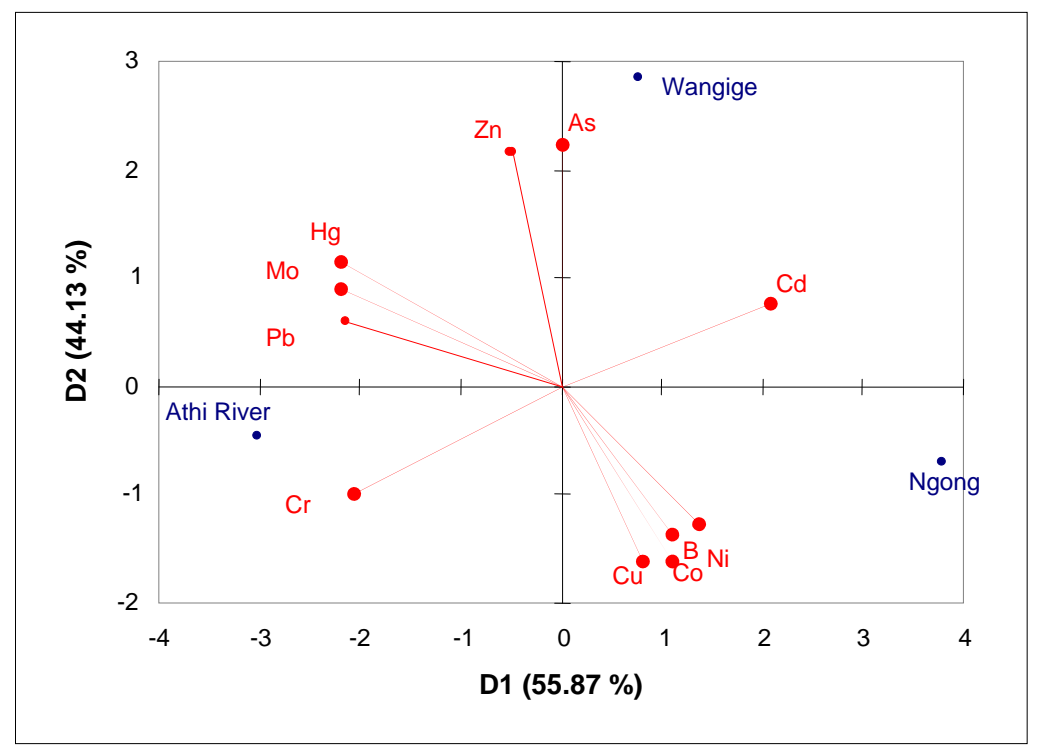

(Jacob, 2007) the World Health Organization (WHO, 2006) notes that boron is toxic to plants in concentrations greater than $0.3-0.5 \mathrm{mg} / \mathrm{L}$. In our study, we found boron concentration to be 0.08 $\mathrm{mg} / \mathrm{L}$, which is lower than the critical limit. Cadmium concentrations in irrigation water from the three locations were below the critical limits, implying that the water was suitable for agriculture. Nickel levels in irrigation water were highest in Athi River $(0.014 \mathrm{mg} / \mathrm{L} \mathrm{Ni})$ compared to Ngong and Wangige $(0.009 \mathrm{mg} / \mathrm{L} \mathrm{Ni})$, exceeding the safe standards for irrigation water approved by NEQS (National Environmental Quality Standards, 1999) of $0.001 \mathrm{mg} / \mathrm{L} \mathrm{Ni}$ in agricultural soil. Cobalt concentrations in irrigation water from the three locations were below the Canadian Water Quality Guidelines (Canadian Council of Resource and Environment Ministers [CCREM], 1987) for irrigation $(0.05 \mathrm{mg} / \mathrm{L})$ Co for irrigation on agricultural soils. However, the slightly elevated Co concentrations found in Athi River could be associated with industrialization and microenterprises, such as vehicle garages in Athi River town. Soils The first principal component, D1, shows that 55.87 percent of the total variance is highly loaded by $\mathrm{B}, \mathrm{Cu}, \mathrm{Co}$, and $\mathrm{Ni}$, which were present in Ngong (figure 3). The heavy loading of As on D1 in soils from Wangige may be attributed to the frequent use of chicken manure laden with this element. This component is thought to comprise heavy metal elements that are inherent in soil, originating mainly from the parent rock, including Zn.

The second component, $D 2$, accounted for $44.13 \%$ of the total variance and was loaded by $\mathrm{Hg}, \mathrm{Mo}$, $\mathrm{Pb}$, and $\mathrm{Cr}$, indicating that their sources are emissions from industrial activities in Athi River town. Concentrations of As in soil varied by site where samples were taken and ranged from 8.15 to $17.72 \mathrm{mg} / \mathrm{kg}$ (figure 4). Normal soil concentrations of As range from 5 to $10 \mathrm{mg} / \mathrm{kg}$ (Kapaj, Peterson, Liber, \& Bhattacharya, 2006). 
Figure 4: Heavy Metal Concentrations in Soil in Peri-urban Sites in Nairobi

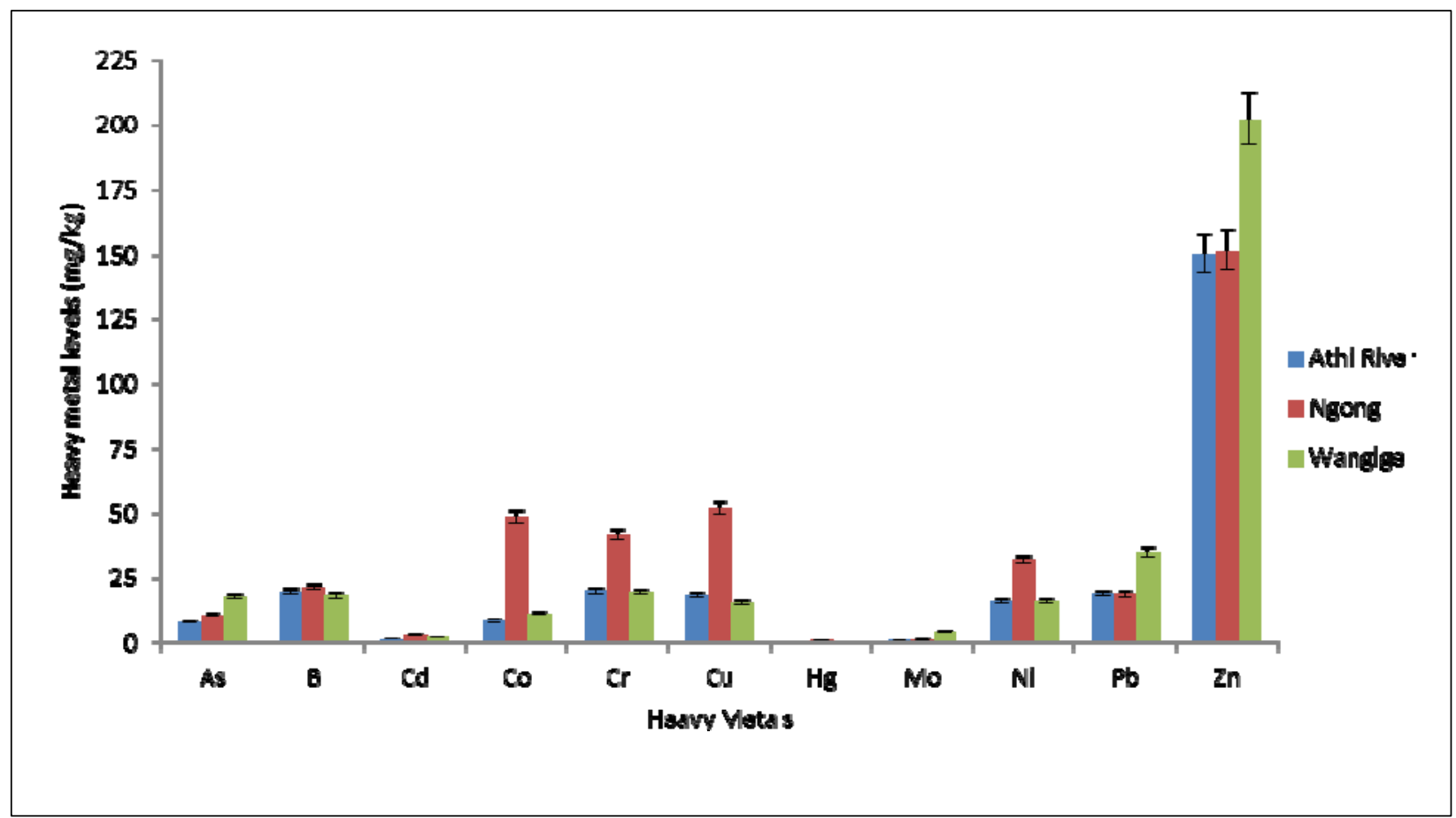

The soils from Wangige contained 17.72 $\mathrm{mg} / \mathrm{kg}$ in average, which surpassed the normal concentrations and indicate that there is a high deposition of As in Wangige. This could emanate from either pesticides or fertilizers, given that the As water concentrations were similar in the three locations. Arsenic in Wangige particularly could be emanating from poultry manure (Hancock, Denver, Riedel \& Miller, 2001). Organic arsenic compounds are commonly added to animal feeds, particularly those for poultry and swine, to control parasites and improve animal growth rates. Poultry manure, which is typically spread on agricultural fields for disposal and as fertilizer, has been shown to contain $15-35 \mathrm{mg} / \mathrm{kg}$ total arsenic (Morrison, 1969). The path of these arsenic feed additives in the environment is not well understood since the organic form of arsenic in poultry manure is rapidly converted into an inorganic form that is highly water soluble and capable of moving into surface and ground water. The boron concentration in Ngong was $14.72 \mathrm{mg} / \mathrm{kg}$ and in Wangige was $22.33 \mathrm{mg} / \mathrm{kg}$, and so both were below the required $25-50 \mathrm{mg} / \mathrm{kg}$ for optimal growth of the crop. Similarly, the Cd levels in soil were below $4 \mathrm{mg} \mathrm{Cd} / \mathrm{kg}$, the critical limit (WHO, 2006): the highest Cd level $(2.63 \mathrm{mg} / \mathrm{kg})$ was recorded in soils from Ngong, followed by Wangige $(2.02 \mathrm{mg} / \mathrm{k})$, with the lowest in Athi River $(1.15 \mathrm{mg} / \mathrm{k})$. Soil $\mathrm{Cr}$ concentration were highest in Athi River and Wangige, with 19.6 and $19.4 \mathrm{mg} / \mathrm{kg}$ deposition, respectively. Livestock manure was also a significant source, contributing approximately 30 percent of $\mathrm{Zn}, \mathrm{Cu}, \mathrm{As}$, and $\mathrm{Cr}$. The guideline for chromium in agricultural soils is approximately 100 $\mathrm{mg} / \mathrm{kg}$ (Karanja et al., 2010).

\section{Manure}

Manure from Wangige was found to contain $\mathrm{Ni}$, $\mathrm{As}, \mathrm{Pb}, \mathrm{Cu}$, and $\mathrm{Zn}$ (figure 5). A study by Nicholson Smith, Alloway, Carlton-Smith, \& Chambers (2003) identified chicken manure as a major source of heavy metals in soil in England and Wales. Similarly Kalavrouziotis, Robolas, Koukoulakis and Papadopoulos (2008) found reported that the use of chicken manure raised the levels of $\mathrm{As}, \mathrm{Ni}, \mathrm{Pb}, \mathrm{Cr}, \mathrm{Cu}$, and $\mathrm{Zn}$ in soils in Greece. Hence the elevated Ni and As concentrations observed in soils collected from Ngong and Wangige farms may have been from chicken 
Figure 5. Heavy Metals in Chicken Manure from Wangige

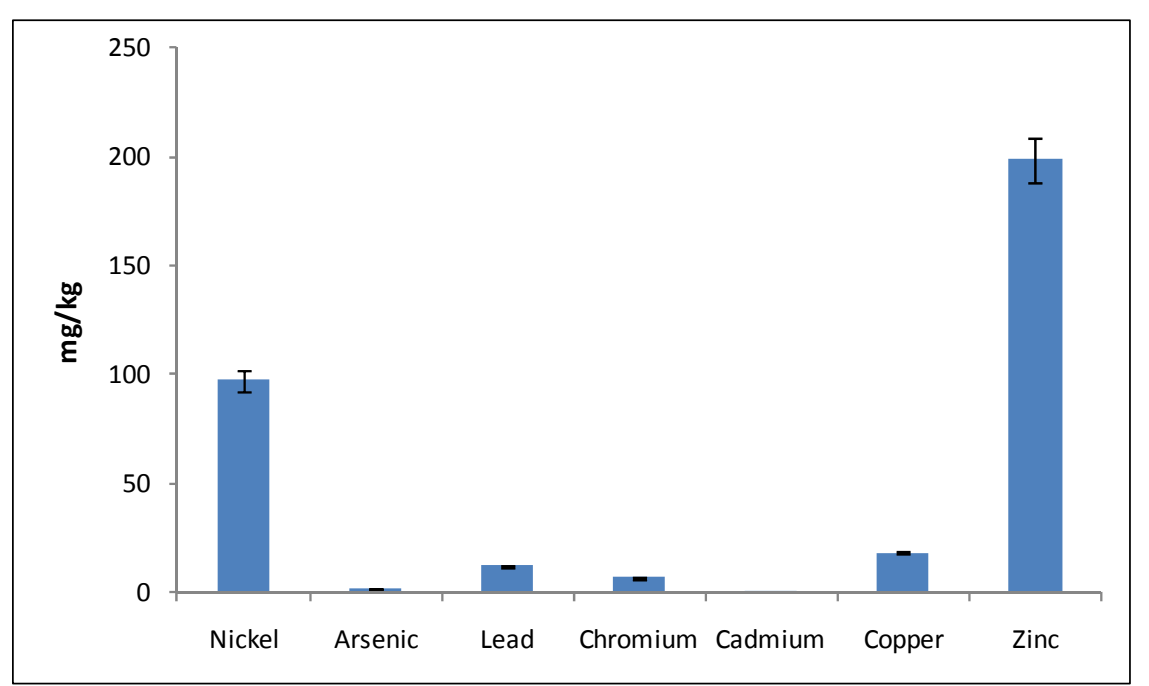

Boron content in vegetables from the peri-urban farms, ranging from 22 to $28.67 \mathrm{mg} / \mathrm{kg}$, had optimal concentrations of this element. It is worth noting that twice the levels of $\mathrm{Cd}$ in kale leaves were recorded in Athi River $(0.02 \mathrm{mg} / \mathrm{kg})$ compared to Ngong $(0.01 \mathrm{mg} / \mathrm{kg})$ and Wangige $(0.01 \mathrm{mg} / \mathrm{kg})$. These concentrations were below the critical limit of $0.2 \mathrm{mg} / \mathrm{kg}$ in all the locations (Muchuweti, Birkett, Chinyanga, Zvauya, Scrimshaw, \& Lester, 2006). $\mathrm{Cd}$ is a natural component of manure fertilization. Total Co was significantly higher in Ngong $(48 \mathrm{mg} / \mathrm{kg})$ compared to Wangige $(11.8 \mathrm{mg} / \mathrm{kg})$ and Athi River $(8.6 \mathrm{mg} / \mathrm{kg})$. The high levels of cobalt in Ngong may be attributed to heavy use of fertilizers, which are enriched with cobalt, generally in the range of $1-12 \mathrm{mg} / \mathrm{kg}$, in order to amend cobalt-deficient agricultural soils. Total cobalt in soils was reported by Hamilton (1994) to generally fall within the range of $0.1-50$ $\mathrm{mg} / \mathrm{kg}$.

\section{Heavy Metal Levels in Kale Leaves}

Although kale normally has a low level of arsenic, we detected significant amounts of arsenic transferred from contaminated wastewater for irrigation to kale (figure 6). Arsenic content in the vegetables ranged from less than $0.01 \mathrm{mg} / \mathrm{kg}$ to $0.4 \mathrm{mg} / \mathrm{kg}$. The maximum allowed limit of consumption of arsenic through food by a person is $0.2 \mathrm{mg} / \mathrm{kg}$ per day (World Health Organization [WHO], 2006). The presence of As in plants entering in the food chain, even in trace amounts, is a primary risk to food safety and human health by given that arsenic is classified as a toxin (WHO, 2006). Exposure to As may lead to hyperpigmentation, keratosis, carcinogenesis, cardiovascular diseases, fetal loss, premature delivery, and long-term loss of memory (Kakar et al., 2006). The major routes of As inputs to agricultural soils include atmospheric deposition, sewage sludge, animal manures, agrochemicals, and inorganic fertilizers (Emongor, 2007). soil, hence its detection in trace levels in vegetable tissues at all the sites. The majority of foodstuffs will contain some $\mathrm{Cd}$, and therefore all humans are exposed to natural levels (Kakar et al., 2006). Bioaccumulation of heavy metals has been shown to vary with plant species, age, environmental conditions, form, and mobility of the metal ions involved (Karanja et al., 2010). The lead levels in kale ranged between $0.39 \mathrm{mg} / \mathrm{kg}$ in Wangige to $3.06 \mathrm{mg} / \mathrm{kg}$ in Athi river, which were above the recommended level of $0.3 \mathrm{mg} / \mathrm{kg}$ (Muchuweti et al., 2006). As indicated by Emongor (2007) and Nabulo et al. (2008), the high $\mathrm{Pb}$ level recorded in Athi River kale leaves $(3.06 \mathrm{mg} / \mathrm{kg})$ results from effluent from the local industries as well as vehicular fumes from the nearby busy MombasaNairobi highway.

The fact that the high variability in lead concentrations in soil did not result in substantial amounts in the leafy tissues of kale is a clear pointer to the immobility of lead in the soil (Emongor, 2007). It is estimated that an adult person of $143 \mathrm{lb} .(65 \mathrm{~kg})$ in Kenya consumes about 7.1 ounces (200 grams) of kale vegetables daily, which translated to ingestion of $0.078 \mathrm{mg}$ to 0.612 $\mathrm{mg} \mathrm{Pb}$, which closely agrees with the amounts reported by Onyang et al. (2008) of $0.5 \mathrm{mg} \mathrm{Pb}$ per day. This dietary lead intake is below the lead limit of $1 \mathrm{mg}$ set by the U.S. Food and Drug Administration Advisory (Gordon \& Wayne, 1993). 


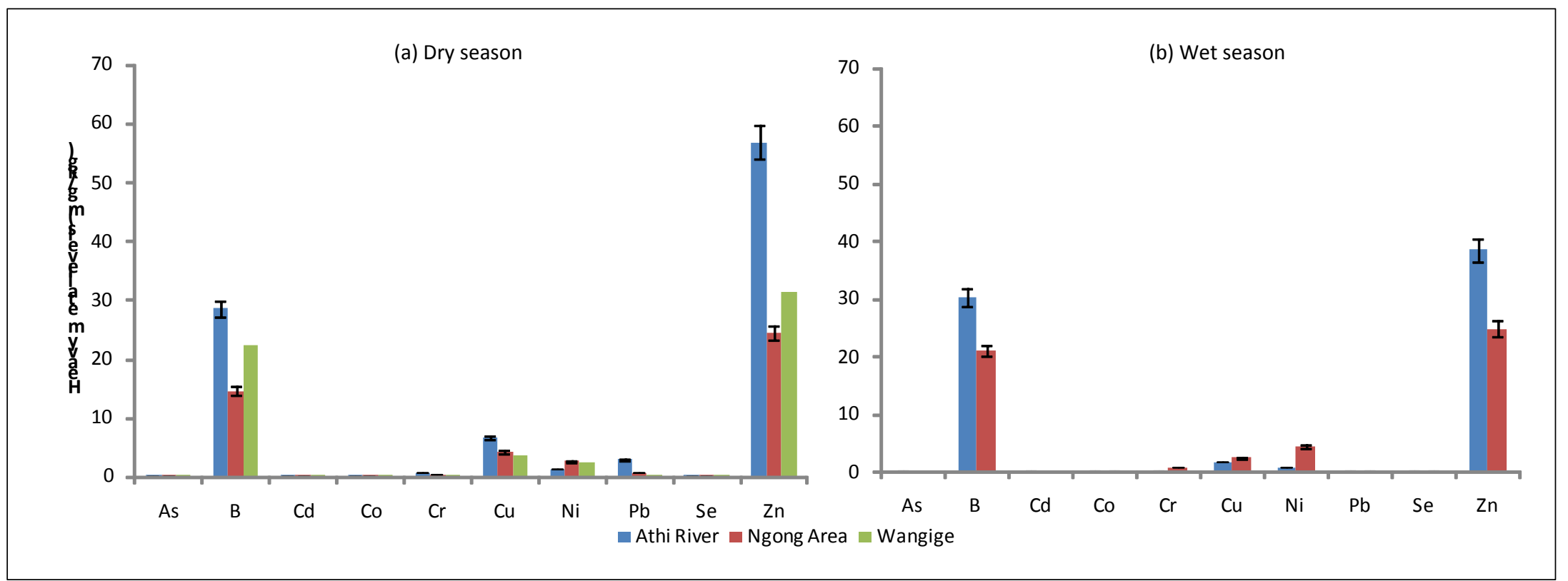

The acceptable limit for human consumption of $\mathrm{Cu}$ is $10 \mathrm{mg} / \mathrm{kg}$ (Nair, Balachandran, Sankarnarayan, \& Joseph, 1997). When $\mathrm{Cu}$ exceeds its safe level concentration, it causes hypertension and sporadic fever, among other conditions. Our study revealed that $\mathrm{Cu}$ varied from 3.6 to $6.7 \mathrm{mg} / \mathrm{kg}$, which falls below the safe limits for human health and hygiene. It is worth noting that the highest concentration of $\mathrm{Cu}$ was found in vegetables in at the Athi River site $(6.7 \mathrm{mg} / \mathrm{kg}$ ), while the lowest concentration of $3.6 \mathrm{mg} / \mathrm{kg}$ was from Wangige, whose farmers use borehole water for opposed to the former, who use waste water for irrigation.

Nickel was also found in kale leaves in the range of 0.76-4.54 $\mathrm{mg} / \mathrm{kg}$. Kale from Ngong showed the highest nickel content during the wet season $(4.54 \mathrm{mg} / \mathrm{kg})$. The acceptable daily intake for Nickel is 3 to $7 \mathrm{mg}$ /day (Agency for Toxic Substances and Disease Registry [ATSDR], 1999), meaning that the amounts reported in this study are within the safety limits of consumption.

Kale tissues accumulated trace levels of Chromium in the three study locations. Cr content could be linked to contaminated irrigation water but more likely to fertilizers and pesticides (Orhue \&

Ekhomun, 2010). Poor waste management practices, particularly where effluent is discharged into the river, is the main source of the higher $\mathrm{Cr}$ levels detected in irrigation water at Athi River. Kale leaf tissues from Wangige and Ngong had $0.52 \mathrm{mg} / \mathrm{L}$ and $0.50 \mathrm{mg} / \mathrm{L}$ levels, respectively, which were above the recommended maximum crop concentration of $0.2 \mathrm{mg} / \mathrm{L}$ Cr (Hide, Kimani, \& Kimani, 2001). Kalavrouziotis and colleagues (2008) have shown that long-term use of irrigation water contaminated with heavy metals may contribute to accumulation of $\mathrm{Ni}$ in soil. It is evident that the continuous use of irrigation water contaminated with $\mathrm{Ni}$ enriched the soil and therefore enhanced accumulation in the soil-plant system (Kalavrouziotis et al., 
Figure 7. Nitrate Levels in Kale from Peri-urban Farms in Nairobi

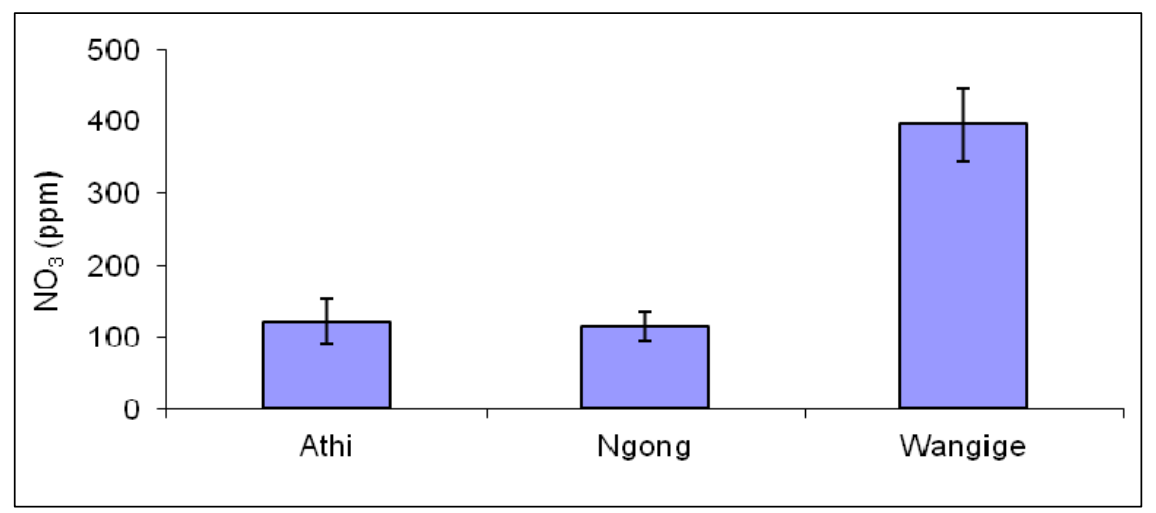

practices. While the maximum initial deposits of cyper-

methrin and deltamethrin were less than their respective MRL values of 1 and 0.2 $\mathrm{mg} / \mathrm{kg}$ for kale, diazinon on the other hand was above MRL of $0.01 \mathrm{mg} / \mathrm{kg}$. Cypermethrin and deltamethrin have been shown to photodegrade rapidly and therefore pose far less risk to humans than organophosphates (Marei, Marei, Ruzo, \& 2008). Various studies have demonstrated that Brassicas olaracea (kale) has very high hyperaccumulation and tolerance for Ni (Giordani, Cecchi, \& Zanchi, 2005; Kabata-Pendias \& Mukherjee, 2007).

Based on the nitrate levels in sampled kale, it was estimated that $0.381 .32 \mathrm{mg}$ nitrates were consumed daily based on the consumption of 7 ounces (200 g) of kale as estimated by Onyango (2008) (figure 7). Nitrate levels found in kale from the three locations were below the recommended daily intake of $0-3.7 \mathrm{mg}$ per $\mathrm{kg}$ of bodyweight according to the World Health Organization (2000). Low levels of nitrate accumulation in the kale leaves could be attributed to the use of organic manures as a source of plant nutrients as opposed to inorganic fertilizers. Onyango and colleagues (2008) demonstrated that increased nitrate accumulation in leaves is often due to a high rate of application of nitrogen fertilizers.

\section{Pesticide Residues in Kale}

This study detected residues of organophosphates (diazinon), pyrethroids (cypermethrin and deltamethrin), and fungicides (triadimenol, prophenos, biternol, and metalaxyl) in the kale leaves (table 1).

Maximum residue limits (MRLs) have been established for individual pesticide/crop combinations by the Joint FAO/WHO Meetings on Pesticide Residues (JMPR), using residue data from supervised trials and recommending uses of pesticides, including good agricultural practices (GAPs) (FAO/WHO, 2009). Exceeded MRLs are strong indicators of violations of good agricultural
Casida, 1982). In addition, microbial degradation may enhance the degradation of the cyper- and delta methrins, which may explain the residue levels below detection limit in this study. Diazinon is an organophosphate insecticide whose toxic action is achieved by inhibiting acetyl cholinesterase, an enzyme essential for normal nerve-impulse transmission. It is highly toxic to humans and animals. Metalaxyl is an agricultural fungicide available in a variety of formulations, many of which include other active ingredients, such as mancozeb, thiabendazole, cymoxanil, and fludioxonil. Trade names are Apron Combi, Apron TZ, Max MZ, Phytospear, Ridomil Gold 2.5G, Ridomil Gold MZ, Speartek, and Wakil XL. Based on international studies, people may be exposed to residues of metalaxyl through their diet, but chronic dietary risk is minimal (U.S. Environmental Protection

Table 1. Pesticide Residues in Kale Samples from Peri-urban Farms in Nairobi

\begin{tabular}{lcc}
\hline Pesticide & Level found $(\mathrm{mg} / \mathrm{kg})$ & EU MRL mg/ $\mathrm{kg}$ \\
\hline Diazinon & $0.04-0.18^{*}$ & 0.01 \\
Metalaxyl & 0.03 & 0.2 \\
Cypermethrin & $0.02-1.1^{*}$ & 0.1 \\
Deltamethrin & 0.04 & 0.5 \\
Triadimenol & 0.03 & 0.1 \\
Biternol & $3.2^{*}$ & 0.05 \\
Profenofos & $4.1^{*}$ & 0.05 \\
\hline
\end{tabular}

*Above the maximum permissible residue levels for the EU community. 
Agency, 1994). In their study, Nasreddine and Parent-Massi (2002) found that vegetables including spinach often contained residues above the permitted levels of maneb, diazinon, cypermethrin, and deltamethrin, among other pesticides. Risks associated with the use of pesticides also could be aggravated by farmers not following the recommended preharvest interval period. This was noted among 85 percent of peri-urban farmers in a study by Ngigi, Njenga, Lagerkvist, Karanja, \& Okello (2011).

\section{Development and Policy Issues for Safe Production of Vegetables in Urban and Peri-Urban Farms}

Wastewater used for irrigation was found to have concentrations of some heavy metals that exceeded recommended levels. The most likely sources of these heavy metals are industries and microenterprises such as motor vehicle garages. Government regulations on disposal of industrial effluent stipulated in Kenya's Environmental and Coordination Act (EMCA) of 1999 should be reinforced through publicity and training of farmers so as to mitigate the risks of using untreated wastewater for crop production, and thus exposing consumers.

Use of pesticides on kale by farmers to protect it from pests and diseases is widespread in Kenya. The motivation to these farmers for applying pesticides is to ensure that kale is good-looking or has high sensory quality attributes in order to meet buyers' aesthetic quality demands. In addition, use of pesticides protects kale from pests and diseases, thus increasing harvestable quantities and generating more money or higher profit margins to growers. However, observing the interval between pesticide application and harvest (i.e., the postharvest interval) is very important to reduce exposure of consumers by ingesting residues in food. The recommended minimum preharvesting interval time between pesticide application and harvest is 15 days for most categories of pesticides. In the survey of 120 farmers (Ngigi et al., 2011) it was observed that only 15 percent observed this recommendation.

Over 70 percent of kale farmers applied livestock manure as a source of crop nutrients. Their reported motivations for applying manure were to improve soil fertility; improve the water-holding capacity of the soil; benefit from the long-lasting effects of manure; ensure that the kale was good looking and had high sensory quality attributes; and produce healthy kale. The long-lasting effects of manure in improving the water-holding capacity result in cost saving through reduced watering. Use of manure also results in savings that would otherwise be used to purchase chemical fertilizer and to hire labor for its application. Elevated levels of heavy metal contamination were detected in the soil samples, especially those meliorated with poultry manure. As a result of these findings, farmers should be made aware of a potential environmental and human health risks. In addition, efforts should be made to increase awareness of National Biofertilizer Use Guidelines (Kenya Bureau of Standards [KEBS], 2011) and where necessary to provide training on the safe use of livestock manure and other organic materials. Nonetheless it is important to note that manure acts as bioremediation agent for contaminated soils by enhancing biological processes by soil organisms.

\section{Conclusions}

This study detected significant amounts of heavy metals transferred from contaminated wastewater used for irrigation to kale. Generally, As, Ni, B, Co, $\mathrm{Cu}$, and $\mathrm{Pb}$ were comparatively elevated at the Ngong and Athi River sites. The elevated heavy metal content in kale leaves was attributed to the use of untreated industrial wastewater used for irrigation. In this study, the highest loading of the heavy metals $\mathrm{Ni}, \mathrm{As}, \mathrm{Pb}, \mathrm{Cr}, \mathrm{Cu}$, and $\mathrm{Zn}$ were demonstrated to be from chicken manure, mainly due to use of commercial feeds. There is limited knowledge of the quality of animal manures and the risk they may pose to the environment and humans as well as effects of heavy metals on uptake of plant nutrients. Nitrate levels were all below the recommended levels, mainly due to farmers' preferred use of organic manures as a source of plant nutrients as opposed to expensive inorganic fertilizers. Finally, violations of GAPs were apparent in the detection of pesticide residues of diazinon, cypermethrin, biternol, and prefenofos exceeding the permissible MRLs. 
We recommend reducing heavy metal contamination by harmonizing and enforcing the various soil, water, and air pollution protection policies in Kenya because bioaccumulation and biomagnification of heavy metals and pesticides residue is associated with human health problems. Due to a lack of information on the consequences of ingesting food contaminated with heavy metals and pesticide residues, there is need for further studies on the effects of these two types of contaminants in human beings. Farmers should be trained on the safe use of pesticides or alternative, environmentally sustainable pest-control strategies. There is a need for researchers, development practitioners, and government extension staff to work together in farmer capacity-building and implementation of guidelines and regulations on safe use of pesticides, manure, fertilizers, and irrigation water. In regard to chicken manure and heavy metal leaching into soil, in order to secure long-term soil fertility, it is recommended that heavy metal content in animal feed should not surpass the chicken nutritional requirements.

\section{References}

Abdel-Ghani, N. T., Hefny, M., \& El-Chaghaby, G. A. F. (2007). Removal of lead from aqueous solution using low cost abundantly available adsorbents. International Journal of Environmental Science and Technology, 4(1), 67-74.

Agency for Toxic Substances and Disease Registry [ATSDR]. (1999). Toxicological Profile for Cadmium and Nickel (Report No. 205-93-0606). Washington, D.C.: U.S. Department of Health and Human Services, Public Health Service.

Aydinalp, C., \& Marinova, S. (2003). Distribution and forms of heavy metals in some agricultural soils. Polish Journal of Environmental Studies, 12(5), 629-633. Retrieved from http://www.pjoes.com/abstracts/ 2003/Vol12/No05/14.html

Campbell, C. R., \& Plank, C. O. (1997). Preparation of plant issue for laboratory analysis. In Y. P. Kalra (Ed.), Handbook of reference methods for plant analysis (pp. 37-50). Boca Raton, Florida: CRC Press.

Canadian Council of Resource and Environment Ministers [CCREM]. (1987, March). Canadian water quality guidelines. Prepared by the Task Force on Water Quality Guidelines of the Canadian Council of Resource and Environment Ministers.
Cornish, G. A., \& Kielen N. C. (2004). Wastewater irrigation - Hazard of lifeline? Empirical results from Nairobi, Kenya and Kumasi, Ghana. In C. A. Scott, N. I. Faruqui, L. Raschid-Sally (Eds.). $W$ astewater use in irrigated agriculture: Confronting the livelihood and environmental realities (pp. 69-79). Ottawa: CAB International in association with the International Water Management Institute and the International Research Development Centre.

Emongor, V. (2007). Biosorption of lead from aqueous solutions of varied $\mathrm{pH}$ by kale plants (Brasiccaoleraceae var acephala). Journal of Agricultural, Food, and Environmental Sciences, 1(2), 1-8.

Ensink, J. H. J., Simmons, R. W., \& van der Hoek, W.(2004). Wastewater use in Pakistan: The cases of Haroonabad and Faisalabad. In C. A. Scott, N. I. Faruqui, \& L. Raschid-Sally (Eds.) W astewater use in irrigated agriculture: Confronting the livelihood and environmental realities (pp. 91-100). Ottawa: CAB International in association with the International Water Management Institute and the International Research Development Centre.

Faruqui, N. I., Niang, S., \& Redwood, M. (2004). Untreated wastewater use in market gardens: A case study of Dakar, Senegal. In C. A. Scott, N. I. Faruqui, \& L. Raschid-Sally (Eds.) W astewater use in irrigated agriculture: Confronting the livelihood and environmental realities (pp. 113-125). Ottawa: CAB International in association with the International Water Management Institute and the International Research Development Centre.

Foeken, D., \& Mwangi, A. M. (2001). Increasing food security through urban farming in Nairobi. In $\mathrm{N}$. Bakker, M. Dubbeling, S. Guendel, U. Sabel Koschella, \& H. de Zeeuw (Eds.), Growing cities growing food: Urban Agriculture on the Policy Agenda (pp. 303-327). Bonn, Germany: German Foundation for International Development (DSE). Retrieved from the RUAF Foundation website: http://www.ruaf.org/node/54

Food and Agriculture Agency [FAO] \& World Health Organization [WHO]. (2009). Pesticide residues in food 2008 (FAO Plant Production and Protection Paper 193). Report of the Joint Meeting of the FAO Panel of Experts on Pesticide Residues in Food and the Environment and the WHO Core Assessment Group on Pesticide Residues. Rome: Authors. Retrieved from http://www.fao.org/docrep/011/ i0450e/i0450e00.htm 
Giordani, C., Cecchi, S., \& Zanchi, C. (2005). Phytoremediation of soil polluted by nickel using agricultural crops. Environmental Management, 36(5), 675-681. http://dx.doi.org/10.1007/s00267-004$\underline{0171-1}$

Gordon, L. K., \& Wayne, R. S. (1993). Heavy metal toxicology. In R. Macrae, R. K. Robinson, \& M. J. Sadler (Eds.), Encyclopaedia of food science, food technology and nutrition (Volume 8, pp. 5198-5200). London: Academic Press.

Hamilton, E. I. (1994). The geobiochemistry of cobalt. Science of the Total Environment, 150(1-3), 7-39. http://dx.doi.org/10.1016/00489697(94)90126-0

Hancock, T. C., Denver, J. M., Riedel, G. F., \& Miller, C. V. (2001, February). Source, transport, and fate of arsenic in the Pocomoke river basin, a poultry dominated Chesapeake Bay watershed. USGS Workshop on Arsenic in the Environment, Denver, Colorado.

Hide, J. M., Kimani, J., \& Kimani Thuo, J. (2001). Informal irrigation in the peri-urban zone of Nairobi, Kenya: An analysis of farmer activity and productivity (Report OD/TN 104). Retrieved from HR Wallingford website: http://books.hrwallingford. co.uk/acatalog/od downloads/odtn104.pdf

Iwegbue, C. M. A., Egobueze, F. E., \& Opuene, K. (2006). Preliminary assessment of heavy metals levels of soils of an oil field in the Niger Delta, Nigeria. International Journal of Environment, Science and Technology, 3(2),167-172.

Jacob, C., (2007). Seawater desalination: Boron removal by ion exchange technology. Desalination, 205(1-3), 47-52. http://dx.doi.org/10.1016/j.desal.2006.06.007

Kabata-Pendias, A., \& Mukherjee, A. B. (2007). Trace elements from soil to human. Berlin: Springer-Verlag.

Kakar, R. G., Yasinzai, M., Salarzai, A. U., Oad, F. C., \& Siddiqui, M. H. (2006). Irrigation with sewage water: Assessment of water quality, nutrients and heavy metal distribution. Asian Journal of Plant Sciences, 5(3), 438-440. http://dx.doi.org/10.3923/ajps.2006.438.440

Kalavrouziotis, I. K., Robolas, P. K., Koukoulakis, P. H., \& Papadopoulos, A. H. (2008). Effects of municipal reclaimed wastewater on the macro- and micro-elements status of soil and of Brassica oleracea var. Italica, and Brassica oleracea var. Gemmifera. Journal of Agriculture Water Management, 95(4), 419-426. http://dx.doi.org/10.1016/j.agwat.2007.11.004
Kapaj, S., Peterson, H., Liber, K., \& Bhattacharya, P. (2006). Human health effects from chronic arsenic poisoning: A review. Journal of Environmental Science and Health, Part A, 41(10), 2399-2428. http://dx.doi.org/10.1080/10934520600873571

Kar, D., Sur, P., Mandal., S. K., Saha, T., \& Kole, R. K. (2007). Assessment of heavy metal pollution in surface water. International Journal of Environment Science and Technology, 5(1), 119-124.

Karanja, N. N., Njenga, M., Prain, G., Kang'ethe, E., Kironchi, G., Githuku, C., Kinyari, P., \& Mutua, G. K. (2010). Assessment of environmental and public health hazards in wastewater used for urban agriculture in Nairobi, Kenya. Tropical and Subtropical Agroecosystems, 12(1), 85-97. Retrieved from http://www.veterinaria.uady.mx/ojs/index.php/ TSA/article/view/367

Kenya Bureau of Standards [KEBS]. (2011). Bio fertilizer - Specification. Kenya Standard (KS 2356).

Retrieved from http://www.inmetro.gov.br/ barreirastecnicas/pontofocal/..\%5Cpontofocal $\% 5 \mathrm{C}$ textos $\% 5$ Cregulamentos $\% 5$ CKEN 306.pdf

Keraita, B., Drechsel, P., Huibers, F., \& Raschid-Sally, L. (2002). Wastewater use in informal irrigation in urban and peri-urban areas of Kumasi, Ghana. Urban Agriculture Magazine, 8, 11-13. Retrieved from RUAF Foundation website: http://www.ruaf.org/node/274

Marei, A. M., Marei, Ruzo, L. O., \& Casida, J. E. (1982). Analysis and persistence of permethrin, cypermethrin, deltamethrin and fenvalerate in the fat and brain of treated rats. Journal of Agricultural and Food Chemistry, 30(3), 558-562. http://dx.doi.org/10.1021/jf00111a037

Moenke-Blankenburg, L. (1993). Laser-ICP spectrometry. Spectrochimica Acta Reviews, 15, 1-37.

Morrison, J. L. (1969). Distribution of arsenic in poultry litter in broiler chickens, soil, and crops. Journal of Agricultural and Food Chemistry, 17(6), 1288-1290. http://dx.doi.org/10.1021/jf60166a018

Muchuweti, M., Birkett, J. W., Chinyanga, E., Zvauya, R., Scrimshaw, M. D., \& Lester, J. N. (2006). Heavy metal content of vegetables irrigated with mixtures of wastewater and sewage sludge in Zimbabwe: Implications for human health. Agriculture, Ecosystems \& Environment, 112(1), 41-48. http://dx.doi.org/10.1016/j.agee.2005.04.028 
Nabulo, G., Oryem-Origa, H., Nasinyama, G. W., Cole, D. C., \& Diamond, M. (2008). Assessment of heavy metal contamination of food crops in wetlands and from vehicle emissions. In D. C. Cole, D. LeeSmith, \& G. W. Nasinyama (Eds.), Healthy city harvests: Generating evidence to guide policy on urban agriculture (pp. 111-131). Lima, Peru: International Potato Center (CIP)/Urban Harvest and Makerere University Press.

Nair, M., Balachandran, K. K., Sankarnarayan, V. N., \& Joseph, T. (1997). Heavy metals in fishes from coastal waters of Cochin, southwest coast of India. Indian Journal of Marine Science, 26, 98-100. Retrieved from http://drs.nio.org/drs/handle/2264/2011

Nasreddine, L., \& Parent-Massin, D. (2002). Food contamination by metals and pesticides in the European Union. Should we worry? Toxicology Letters, 127(1-3), 29-41. http://dx.doi.org/10.1016/S0378-4274(01)00480-5

National Environmental Quality Standard for Municipal and Liquid Industrial Effluents. (1999). Compiled and distributed by National Scientific Corporation, Pakistan.

Ngigi, M., Njenga, M., Lagerkvist, C. J, Karanja, N., \& Okello, J. (2011). Measures to reduce food safety risks in urban and peri-urban leafy vegetables value chain in Nairobi, Kenya [Feedback Workshop Report].

Nicholson, F. A., Smith, S. R., Alloway, B. J., CarltonSmith, C., Chambers, B. J. (2003). An inventory of heavy metals inputs to agricultural soils in England and Wales. Science of the Total Environment, 311(1-3), 205-219. http://dx.doi.org/10.1016/S00489697(03)00139-6

Nugent, R. (2001). The impact of urban agriculture on the household and local economies. In N. Bakker, M. Dubbeling, S. Guendel, U. Sabel Koschella, \& H. de Zeeuw (Eds.), Growing cities growing food: Urban Agriculture on the Policy Agenda (pp. 67-97). Bonn, Germany: German Foundation for International Development (DSE). Retrieved from the RUAF Foundation website: http://www.ruaf.org/node/54
Okello, J. J., Lagerkvist, C.-J., Hess, S., Ngigi, M., \& Karanja, N. (2012). Choice of fresh vegetable retail outlets by developing-country urban consumers: The case of kale consumers in Nairobi, Kenya. European Journal of Development Research, 24, 434-449. http://dx.doi.org/10.1057/ejdr.2011.58

Onyango, C. M., Shibairo, S. I., Imungi, J. K., \& Harbinson, J. (2008). The physico-chemical characteristics and some nutritional values of vegetable amaranth sold in Nairobi-Kenya. Ecology of Food and Nutrition, 47(4), 382-398. http://dx.doi.org/10.1080/03670240802003926

Orhue, E. R., \& Ekhomun, A. M. (2010). Chromium effects on early growth of water leaf (Talinum triangulare) in an Ultisol. American-Eurasian Journal of Agricultural and Environmental Science, 7(5), 586-590.

Retrieved from IDOSI website: http://www.idosi. org/aejaes/jaes 7\%285\%29/15.pdf

Qishlaqi, A., Moore, F., \& Forghani, G. (2008). Impact of untreated wastewater irrigation on soils and crops in Shiraz suburban area, SW Iran. Environmental Monitoring and Assessment, 141(1-3), 257-273. http://dx.doi.org/10.1007/s10661-0079893-x

U.S. Environmental Protection Agency. (1994). EPA R.E.D. Facts: Metalaxyl (Series 7508W, Report No. EPA-738-F-94-013). Washington, D.C.: Author.

Williams, M. (2001). Arsenic in mine waters: An international study. Environmental Geology, 40(3), 267-278. http://dx.doi.org/10.1007/s002540000162

World Health Organization [WHO]. (2000). The world bealth report 2000 - Health systems: Improving performance. The World Health Report. Geneva: Author. Retrieved from http://www.who.int/whr/2000/en/

World Health Organization [WHO]. (2006). WHO guidelines for the safe use of wastewater, excreta and greywater (Volume 2, Wastewater Use in Agriculture). http://www.who.int/entity/water sanitation health/wastewater/guidelines order form.pdf 